\title{
Flow dependent water quality impacts of historical coal and oil shale mining in the Almond River Catchment, Scotland
}

\author{
Simon Haunch ${ }^{1^{*}}$, Alan M, MacDonald ${ }^{2}$, Neil Brown ${ }^{3}$, Christopher I. McDermott ${ }^{1}$ \\ ${ }^{1}$ Edinburgh University, School of Geosciences, Kings Buildings, Edinburgh, EH9 3JW \\ ${ }^{2}$ The British Geological Survey, Kings Buildings, Edinburgh, EH9 3 LA \\ ${ }^{3}$ West Lothian Council, County Buildings, High Street, Linlithgow, EH49 7EZ \\ "Corresponding author. E-mail: S.Haunch-2@sms.ed.ac.uk, Tel: +44 (0) 131650 5931, Mob: +44 (0) \\ 7732433439, Fax: +44 (0) 1316683184
}

\begin{abstract}
The Almond River Catchment in Central Scotland has experienced extensive coal mining during the last 300 years and also provides an example of enduring pollution associated with historic unconventional hydrocarbon exploitation from oil shale. Detailed spatial analysis of the catchment has identified over 300 abandoned mine and mine waste sites, comprising a significant potential source of mine related contamination. River water quality data, collected over a 15 year period from 1994 to 2008, indicates that both the coal and oil shale mining areas detrimentally impact surface water quality long after mine abandonment, due to the continued release of iron and sulphate associated with pyrite oxidation at abandoned mine sites. Once in the surface water environment iron and sulphate display significant concentration-flow dependence: iron increases at high flows due to the re-suspension of river bed iron precipitates $\left(\mathrm{Fe}(\mathrm{OH})_{3}\right)$; sulphate concentrations decrease with higher flow as a result of dilution.

Further examination of iron and sulphate loading at low flows indicates a close correlation of iron and sulphate with mined areas; cumulative low flow load calculations indicate that coal and oil shale mining regions contribute 0.21 and $0.31 \mathrm{~g} / \mathrm{s}$ of iron, respectively, to the main Almond tributary. Decreases in iron loading along some river sections demonstrate the deposition and storage of iron within the river channel. This river bed iron is re-suspended with increased flow resulting in significant transport of iron downstream with load values of up to $50 \mathrm{~g} / \mathrm{s}$ iron. Interpretation of major ion chemistry data for 2005-6 indicates significant increases in $\mathrm{Ca}^{2+}, \mathrm{Mg}^{2+}$ and $\mathrm{HCO}_{3}{ }^{-}$in coal mined areas probably as a result of the buffering of proton acidity in mine waters; in the oil shale areas $\mathrm{Na}^{-}$and $\mathrm{Cl}^{-}$become increasing dominant possibly associated with increased urbanisation and saline pore waters discharge from unprocessed oil shales wastes.
\end{abstract}

The study demonstrates importance of considering the cumulative impact of point and diffuse contamination sourced from numerous small coal and oil shale mine sites on surface water quality. 


\subsection{Introduction}

Production of heavily mineralised discharge waters is a phenomenon observed world wide at active and abandoned mine sites (e.g. Ahmad, 1974; Hedin et al., 1994; Banks et al., 1997a; Wood et al., 1999; Blowes et al., 2003). Mine closure commonly results in increased concentrations of dissolved ions, particularly iron and sulphate, in mine discharge waters due to the dissolution of pyrite oxidation products formed, principally, during the operational phase of the mine (Cairney \& Frost, 1975; Bowen et al., 1998; Younger, 2000a). Waste rock brought to the surface in the process of mining can also produce similar mine waters, via pyrite oxidation, on exposure to atmospheric oxygen and precipitation (Bell, 1996; Banks et al. 1997b; Rees et al., 2002; Lottermoser 2010; Nordstrom, 2011). When discharged at the surface mine waters can have serious environmental consequences for water quality in recipient streams and rivers (Younger, 1995; Banks et al., 1997a, Jarvis \& Younger 1997). Oxidation and precipitation of iron forms ocherous precipitates in the surface water column which, once settled, smother river beds and impact river ecology (Edwards and Maidens 1995). The processes of pyrite oxidation, carbonate buffering (which reduces acidity in mine waters (Hedin et al. 1994, Banks et al 1997a, Wood et al., 1999)) and iron precipitation in surface waters is well characterised for individual coal mine sites (e.g. Chen et al., 1999, Younger, 2000a). The environmental impact of oil shale mining, however, is poorly characterised. The Almond River Catchment provides an example of enduring water pollution from historic oil shale exploitation, which has particularly significance due to the modern day interest in unconventional hydrocarbon exploitation, potentially in the remaining shales (DEC, 2011), and concerns about associated pollution.

Oil shale and coal bearing rocks have similar pyrite content, normally around 1-2\% (Louw and Addison, 1985), and both are associated with marine deposition (Francis, 1983). Pyrite oxidation and carbonate buffering reactions are, therefore likely to be of principal control on oil shale mine water chemistry (Erg, 2005). Within Scotland, oil shale mine waste differs to coal mine waste as following exhumation from the mine oil shale was heated to extract the organic fraction of the shale as a form of crude oil (Carruthers et al. 1927). This produced two oil shale mine wastes: (1) overburden mine waste, derived from the mining process, which may contain pyrite, (2) processed waste likely to lack pyrite due to the application of heat during processing. In the Almond River Catchment, the oil shale mine 
wastes sites which can rise up to $95 \mathrm{~m}$ (Harvie, 2005) are dominated by orangey red burnt processed waste. However, discrete layers and sections of waste piles are formed from the second, generally black un-processed, shale overburden mine waste. Therefore, the oil shale waste sites are a composite of the volumetrically dominant processed oil shale, which is unlikely to produce mine waters and the unprocessed oil shale mine waste likely to contain pyrite and potentially produce $\mathrm{Fe}$ and $\mathrm{SO}_{4}$ bearing mine waters.

In recent years significant advances have been made in the assessment of mine water hazard and impact as well as in remediation technology design to reduce the impact of point source mine water contamination on surface water and groundwater (e.g. Heal\& Salt, 1999; Younger, 2000a, 2000b; Gandy \& Younger 2003; Evans et al., 2003; Jarvis et al, 2006). Some studies, such as that undertaken by Mayes et al (2008), indicate that water quality in mined catchments is heavily influenced by diffuse mine water inputs. However, impacts on water quality on the river catchment scale from mine water contamination is less well studied than the impact of individual coal mines. Recent European (Water Framework Directive; 2000/60/EC) and national legislation (Water Environment and Water Services Act (Scotland) 2003) encourages consideration of water quality pressures on the river catchment scale and the scientific community is increasingly advocating this scale of approach to deal with mine related contamination (eg. Kimball et al 1999, 2000; España et al 2005, Mayes et al 2008).

The aim of this paper is to assess the impact of historic coal and oil shale mining on surface water quality and characterise the flow dependency of mine water contaminants in the surface water environment. We do this by the construction of a GIS data base of historic mines in the catchment and correlate this to the source and transport of mine related contamination in surface water under variable flow conditions. Over 15 years of surface water quality from 19 points in the catchment, with corresponding river flow data, is analysed focusing specifically on $\mathrm{Fe}$ and $\mathrm{SO}_{4}{ }^{2-}$, as the products of pyrite oxidation at mine sites, supported by $\mathrm{pH}$, dissolved oxygen and major ion data. 


\subsection{Study Area}

The Almond River Catchment is located in the central belt of Scotland, between Glasgow and Edinburgh (Figure 11). The catchment comprises approximately $370 \mathrm{~km}^{2}$ of mixed urban and semi-agricultural land, of which up to $50 \%$, by land area, has been affected by variable amounts of historic mining activity. Both coal and oil shale were mined in the catchment; coal from pre $17^{\text {th }}$ century to the mid 1980 s and oil shale from 1860 s to the 1960 s. The mining industries and the legacy of abandoned mine sites has resulted in significant impacts on surface water and groundwater quality in the catchment. Surface water quality is amongst the worst in Scotland (Pollard et al., 2001) and the overall quality status of surface water and groundwater is classified by SEPA as poor (SEPA, 2009-2015). Previous studies have presented data form coal mine waters discharges in the Almond including Polkemmet, Riddochill (Chen et al 1999, O Dochartaigh et al., 2011) and Cuthill (Younger 2001), and indicate that waters are generally net alkaline with elevated iron concentrations up to $50 \mathrm{mg} / \mathrm{l}$.

Historic mining was intensive and widespread with over 300 sites relating to the extraction or disposal of mined or quarried mineral resources, the majority of which relate to coal and oil shale mining, although less amounts of ironstone, limestone, slate, sandstone, metals and clay were also mined. Mine waters and the resulting surface water and groundwater contamination are not associated with every mine site, however, the number and density of abandoned mine sites in the catchment gives an indication of the scale of potential environmental impact (Figure 22). 


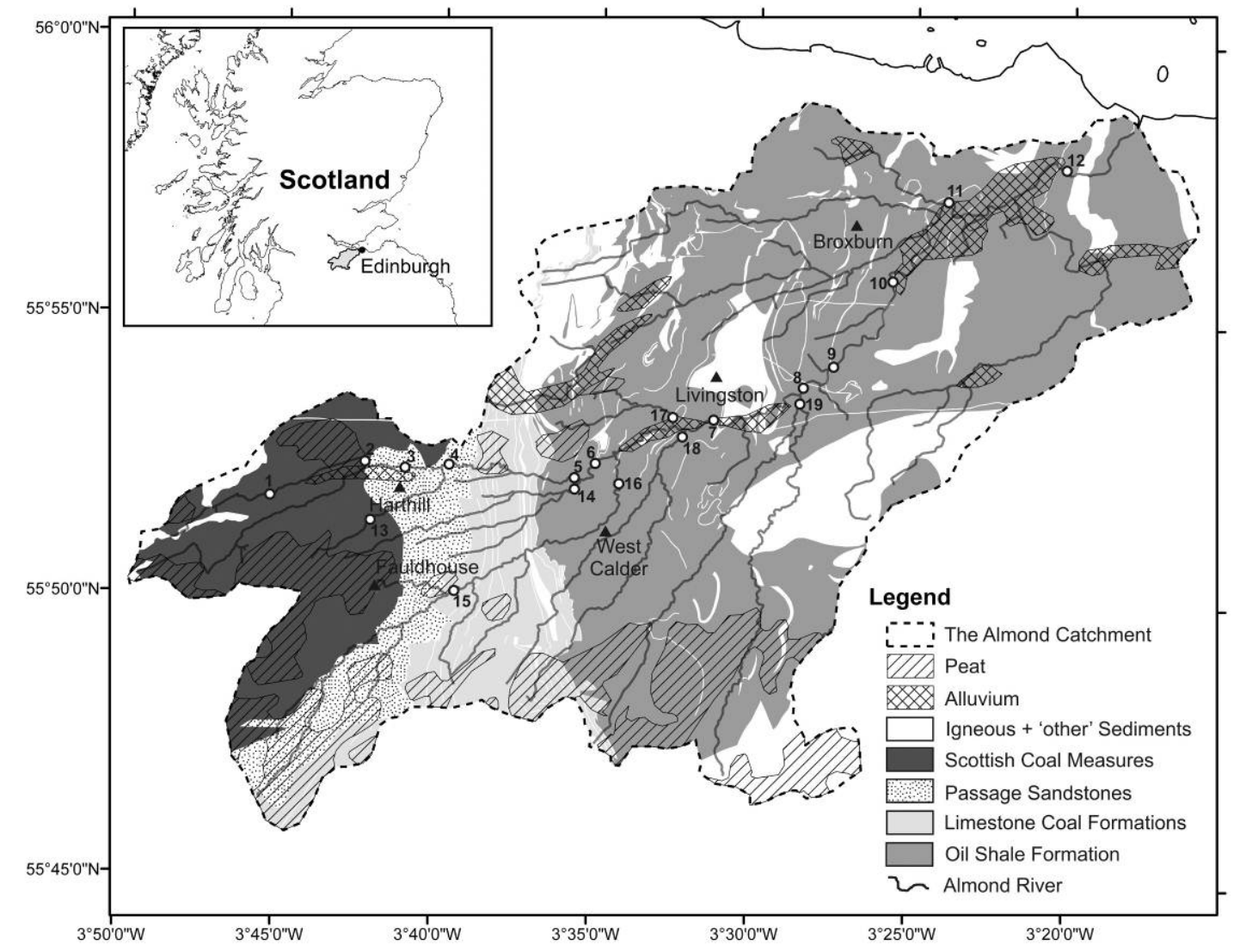

Figure 1- Geology and Surface Water Monitoring Network in the River Almond Catchment. Derived from BGS digital geological mapping at 50,000 scale, British Geological Survey (C) NERC. Contains Ordnance Survey data (C) Crown Copyright. Licence No. 100021290

\section{$2.1 \quad$ Geology}

The Almond River catchment geology is dominated by a series of thick marine and deltaic Carboniferous aged sedimentary deposits (

Table 11), part of the larger sedimentary sequence which composes the rocks of the Midland Valley, Scotland. The sediments appear in depositional cycles representing changes in the depositional regime of the Carboniferous sedimentary basin in which they were deposited. Principally, these cycles represent regressions from shallow marine to terrestrial environments coupled with periodic rises in sea level and local and regional subsidence defined by the Southern Uplands and Highland Boundary fault. The present day complex outcrop structure (

Figure 11) was caused by significant folding and faulting associated with a complex structural and volcanic history in the region (Francis, 1983; Cameron and Stephenson, 1985). 
The geology of the catchment is significant because it provides the framework for the mine site distribution, the pyrite source minerals for the production of mine contamination and the carbonate minerals which buffer acidity. However, while carbonate buffering results in the majority of Scottish mine waters being net-alkaline (Younger 2001), buffering capacity is unlikely to result from calcite dissolution as limestones are relatively rare in the coal bearing formations (Table 11) and where present are generally dolomitic. The principal buffering capacity is likely to originate instead from Ankerite $\left(\mathrm{Ca}(\mathrm{Mg}, \mathrm{Fe})\left(\mathrm{CO}_{3}\right)_{2}\right)$, a common secondary mineral on coal fracture surfaces (Thomas, 2002), which acts as a net consumer of acidity but also as a potential source for iron in mine waters (Younger, 2004).

\begin{tabular}{|c|c|c|c|c|}
\hline Period & Group & Formation & Description & Map Reference \\
\hline \multirow{6}{*}{$\begin{array}{l}\text { Upper } \\
\text { Carboniferous }\end{array}$} & \multirow{2}{*}{$\begin{array}{l}\text { Coal Measures } \\
\text { (Scotland) }\end{array}$} & Middle Coal Measures & $\begin{array}{l}\text { Cyclic sequences of sandstones, siltstones, } \\
\text { mudstones, ironstones, coals and seatrocks }\end{array}$ & \multirow[t]{2}{*}{ Coal Measures } \\
\hline & & Lower Coal Measures & $\begin{array}{l}\text { Cyclic sequences of sandstones, siltstones, } \\
\text { mudstones, ironstones, coals and seatrocks }\end{array}$ & \\
\hline & \multirow[t]{4}{*}{ Clackmannan Group } & Passage Formation & $\begin{array}{l}\text { Mainly sandstones with fireclays and thin } \\
\text { sitstones, mudstones, ironstones and thin coals }\end{array}$ & Passage Sandstones \\
\hline & & Upper Limestone Formation & $\begin{array}{l}\text { Cyclic sequences of sandstones, siltstones, } \\
\text { mudstones, marines limestones and a few coals }\end{array}$ & \multirow[t]{3}{*}{$\begin{array}{l}\text { Limestone Coal } \\
\text { Formations }\end{array}$} \\
\hline & & Limestone Coal Fomration & $\begin{array}{l}\text { Cyclic sequences of sandstones, siltstones, } \\
\text { mudstones, ironstones, coals and seatrocks }\end{array}$ & \\
\hline & & Lower Limestone Formation & $\begin{array}{l}\text { Cyclic sequences of sandstones, siltstones, } \\
\text { mudstones, marines limestones and a few coals }\end{array}$ & \\
\hline \multirow[t]{4}{*}{$\begin{array}{l}\text { Lower } \\
\text { Carboniferous }\end{array}$} & \multirow[t]{2}{*}{ Strathclyde Group } & $\begin{array}{l}\text { West Lothian Oil Shale } \\
\text { Formation }\end{array}$ & $\begin{array}{l}\text { Mainly sandstones with siltstones, mudstones } \\
\text { and oil-shales, thin coal seams and limestones }\end{array}$ & Oil Shale Formations \\
\hline & & Gullane Formation & $\begin{array}{l}\text { Sandstone, grey and green, siltsone and } \\
\text { mudstone }\end{array}$ & \multirow[t]{3}{*}{ 'Other Sediments' } \\
\hline & \multirow[t]{2}{*}{ Inverclyde Group } & Ballagan Formation & $\begin{array}{l}\text { Sandstone, grey and red, siltsone, mudstone } \\
\text { and dolomitic limestone }\end{array}$ & \\
\hline & & Kinneswood Formation & $\begin{array}{l}\text { Sandstone, pink, red-brown and white with } \\
\text { siltsone and mudstone }\end{array}$ & \\
\hline
\end{tabular}

Table 1 Geology and Economic Geology of the main Carboniferous deposits of the Almond River Catchment (Francis, 1983, Cameron and Stephenson, 1985)

\subsection{Data and Methods}

Extensive and detailed datasets of the geology and hydrogeology, water quality and land use history of the Almond River catchment were acquired from the British Geological Survey (BGS), Scottish Environment Protection Agency (SEPA) and West Lothian Council (WLC) respectively.

\subsection{Spatial Analysis}

Mine datasets provided by WLC and the BGS were refined through field observations and analysis of historic data sources (Winter, 2001; MacDonald et al, 2003). Mine location data were refined to identify the dominant mine type (i.e. subsurface, opencast or mine waste site) and mined mineral resource. Historic land use data were then compared, in ARC GIS, to 
the geological and hydrogeological data. Principal mining areas relating to different mined resource were identified. Spatial comparison of field data and surface water quality data sets was then undertaken.

\subsection{Water Quality Data}

Comprehensive monthly to two-monthly sampling, dating back to 1994 , is undertaken by SEPA at 19 monitoring points (Figure 11) on tributaries in the catchment, 1-12 on the main Almond tributary, 13-19 on second order tributaries. Sampled waters are analysed, by SEPA, for a number of analytical suites tailored to SEPA's requirements with respect to different water pressures including mining, urban drainage and sewage treatment. The data used in this study was extracted from this wider water quality data set in order to specifically consider mine water related water quality pressures. In general $\mathrm{Fe}_{\text {tot }}, \mathrm{pH}$ and dissolved oxygen are available at all the monitoring points 1-19 in the catchment, sulphate was available at selected monitoring points $(1-6,10$ and 12$)$ on the main Almond tributary. $\mathrm{Fe}_{\text {tot }}$ is iron analysed in an unfiltered river water sample and therefore considers all the iron species in the sample, both dissolved and solid. Since 2007, a sample of Fe sampled through a $0.45 \mu \mathrm{m}$ filter has also been collect, $\mathrm{Fe}<0.45 \mu \mathrm{m}$, which is generally considered to only contain dissolved Fe species. This data is used to consider differences in Fe speciation in river waters.

River loads of iron and sulphate are calculated using daily flow readings from SEPA's 4 flow gauging stations in the catchment (Whitburn, Almond Wier, Almondell and Cragiehall). Flow readings at the monitoring points $\left(Q_{c}\right)$ are calculated by multiplying the flow reading at the nearest gauging station $\left(\mathrm{Q}_{\mathrm{g}}\right)$ by a correction factor calculated from the relative catchment area ratio of the monitoring point $\left(C_{c}\right)$ and nearest gauging station $\left(C_{g}\right)$.

$\mathrm{Q}_{\mathrm{c}}=\mathrm{Q}_{\mathrm{g}}\left(\mathrm{C}_{\mathrm{c}} / \mathrm{C}_{\mathrm{g}}\right)$

Where the catchment ratio $(\mathrm{Cc} / \mathrm{Cg})$ is close to 1 then the flow estimates and the associated load calculations are most accurate. This is generally the case for monitoring points 1-12 due to the proximity of monitoring points to gauging stations. Monitoring points $13-19$ have lower catchment ratios and therefore give less accurate flow estimations and load calculations. As a result interpretations based on the load calculations are generally only 
made using data from monitoring points 1-12, data from points $13-19$ are used only to support these interpretations.

The concentration and load of contaminants are considered under low flow and high flow conditions in the river catchment. Low flow is defined here as flow values falling below the $30^{\text {th }}$ percentile for the distribution of flow values recorded at each monitoring point during the monitored period (1994-2008 Fe, 1994-2006 $\mathrm{SO}_{4}{ }^{2-}$ ); high flows are those flow values above the $90^{\text {th }}$ percentile in the distribution.

Additional data on the concentration of major ions (calcium, magnesium, potassium, sodium, chloride, bi-carbonate, sulphate and nitrate) was also available for the years 200506 for monitoring points 1-12, this has been used to look at variations in the bulk river water chemistry in the Almond River.

\subsection{Results \& Discussion}

\subsubsection{Mine Distribution}

The scale and distribution of mining and the resulting mine waste across the Almond catchment is not uniform and several distinct areas of mining activity can be identified (Figure 22). Coal mining dominated in the south west of the catchment, targeting coals in the Scottish Coal Measures, Passage Formation and Limestone Coal Formations. Oil shale mining dominated in the central east of the catchment targeting the 6 workable oil shale horizons, the Pumpherston, Camps, Dunnet, Champfleurie, Broxburn and Fells seams in the Oil Shale group (Kerr, 1994). The clear geographic divide between the coal and oil shale dominant mining regions is identified by the dashed line in Figure 22.

\subsubsection{Mine History}

Early mining in the catchment targeted shallow accessible coal and oil shale seams and produced only small amounts of mine waste. Deeper mining, which produced increased mine waste and mine water volumes, came later as the result of advances in water technology (Duckham, 1970) and increased demand in the coal market (Hassan, 1976). 
During the $19^{\text {th }}$ century coal mining in Scotland saw considerable investment and growth however this wasn't reflected until after the 1840s in the mines of the Lothian coal fields (Hassan, 1976) and the Almond River Catchment. After the 1840s, modernisation of the coal and transport industries and changes in the industrial and social landscape facilitated growth (Hassan, 1976). Around this time in the 1850s innovations in hydrocarbon extraction technologies, by James Young, resulted in the mining and exploitation of oil shale deposits in the catchment and the growth of the oil shale industry. The coal and oil shale industries in the area produced one of the UK most heavily mined catchments which contained Scotland's most productive coal mine, Polkemmet (Oglethorpe, 2006).

Opencast, shallow and deep mining was utilised over the lifetime of the coal industry. Most opencast mines were limited in their extent and were generally reinstated upon closure; no mine pit lakes occur in the catchment. Shallow coal mines were generally older, locally operated mines that although numerous were limited financially in their working depth, due to the expense of mining equipment and water pumps. Deeper mines such as, Polkemmet 1916-1984 (Shaft 2, 470m), Whitrigg 1900-1972 (Shaft 5, 323m), Riddochhill 1890-1968 (Shaft $1,289 \mathrm{~m}$ ) came later in the early to mid-20 ${ }^{\text {th }}$ century and were managed initially by large private companies and then by the National Coal Board following nationalisation in 1947 (Oglethorpe, 2006). The volumes of mine waste produced from coal mining although environmentally significant, due to the generally acidic nature, were smaller than the neighbouring oil shale industry.

The Oil Shale industry employed opencast, shallow and deep mining methods. The majority of early oil shale mines were opencast however 'inclined', or 'drift' type mines became common place as the industry developed. Pits or shafts, which were typically between 400700 feet $(120-210 \mathrm{~m})$, were used to intersect drift mines or to access deeper shale seams (Kerr, 1994). Oil shale was mined and transported to the oil shale processing sites, of which there was over 100 at the peak of the industry, then the oil shale waste was deposited in large accumulations, known locally as 'Bings'. Almost the entire mined volume of the Oil Shale industry was deposited as waste following the extraction of the oil shales' $14 \%$ organic content (Yen and Chilingarian, 1976). The 'bings' also contain a significant proportion of black unprocessed shale waste originating from mining process. Estimates 
suggest there are 150 million tonnes of waste within West Lothian resulting from the Oil Shale industry (McAdam et al., 1992).

Oil shale mining went into decline in the early $20^{\text {th }}$ century, due to competition from American oil, finally closing in the 1960s after the withdrawal of over forty years of government tax relief (Louw and Addison, 1985). Coal mining continued until widespread UK closure began in the 1980s. Mine closure in the catchment has resulted in the production of numerous coal and oil shale mine discharge waters from both subsurface mines and surface waste deposits.

\subsubsection{Previous environmental assessments and management}

The environmental impact of mining on the quality of river waters in the catchment today is both significant and widespread (SEPA, 2009-2015), however the historic impact was noted back in the 1870's when fish stocks in the river were almost completely wiped out (Pollard et al., 2001). Coal solids being washed down-stream were also a serious historic problem. In 1892 (Brock, 1892) when the medical officer of health for Mid Lothian was asked to survey the Almond River he described the river's extremely poor water quality;

'The water along its whole course has an ochry colour. Fish cannot live in it. Horses, cattle and sheep drink sparingly of it, if at all, and for industrial purposes it is almost useless on account of its destructive effects upon boilers.' W.J. Brock 1892

Improvements in working practices at mine sites and the decline in the processing of oil shale is likely to have improved water quality in the river waters in the latter half of the $20^{\text {th }}$ century. However, closure of the coal mines in the 1980 s only increased the environmental threat as the cessation of dewatering activities had the potential for the surface break out of iron rich mine waters (Younger, 1994, Wood et al., 1999). The deep Polkemmet colliery is still pumped today to prevent the dissolution of pyritic salts into rising groundwaters; pumped waters are then treated, prior to discharge, to limit the environmental impact on the recipient surface waters. Many of the smaller, older collieries were probably allowed to flood and produce mine waters which break out uncontrollably at surface following closure. Little to no environmental management was put in place during the closure of oil shale mining activities as all were close prior to the 1960s. Significant advances have been made in recent years in improving water quality through mine water treatment schemes and 
remedial activities at old opencast and mine waste sites. However, historically the impact of mining activities was one of the principal factors in downgrading quality classifications on a large number of the Almond River catchment's tributaries (Campbell et al., 1996).

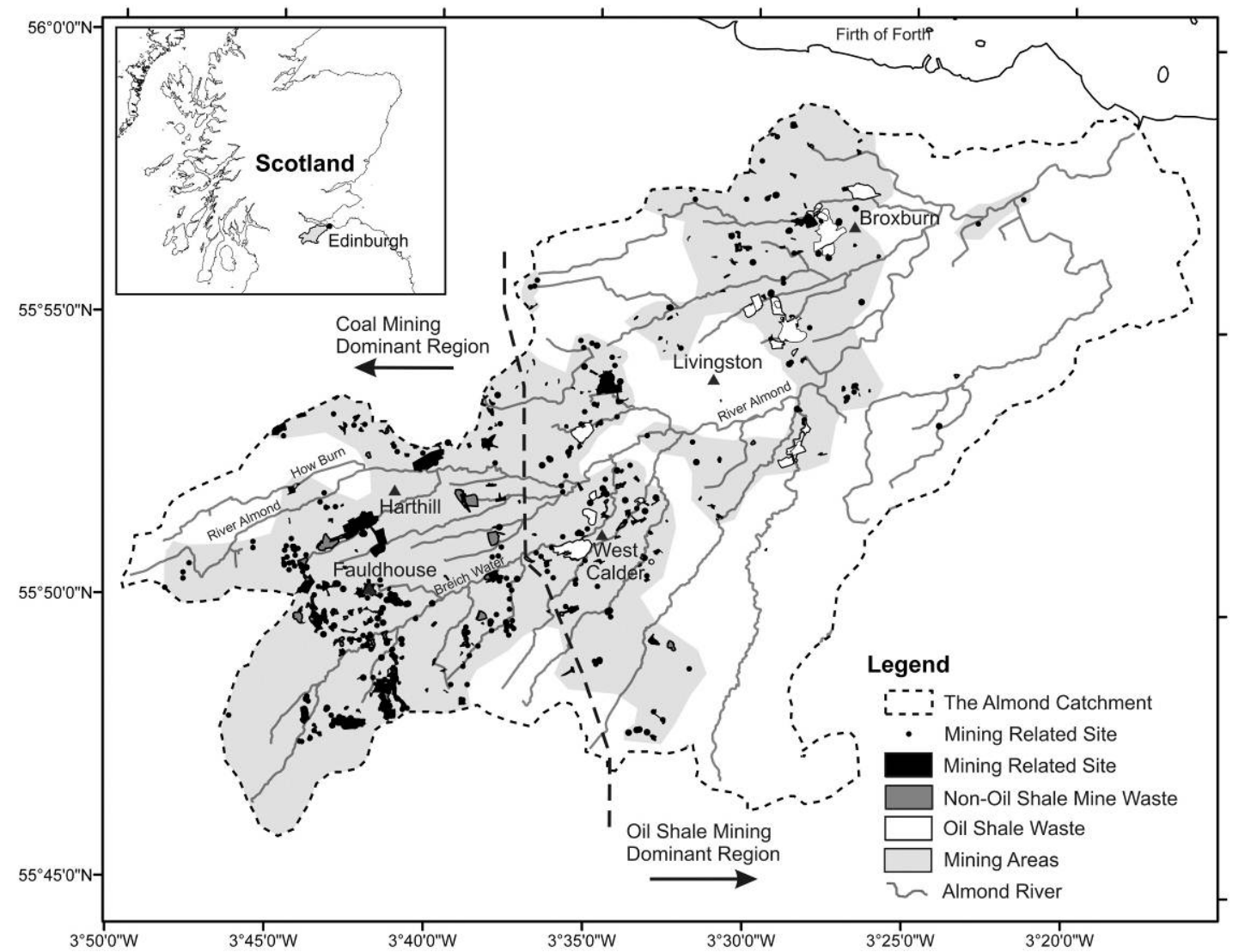

Figure 2- Mine Site Distribution in the Almond River Catchment. Contains Ordnance Survey data (C) Crown Copyright. Licence No. 100021290

\subsection{Water Quality}

Iron and sulphate data for the 19 surface water monitoring points in the catchment (12 on the main Almond tributary, 7 on smaller second and third order tributaries) are summarised in Table 2. Data indicate iron and sulphate in surface waters of the Almond basin are elevated compared to other rivers in Scotland (e.g. Soulsby et al., 2005, SEPA, 2009-2015). Neal (2011) presents average concentration data (Fe 0.13-0.54 mg/l, SO ${ }_{4}^{2-}-6-116 \mathrm{mg} / \mathrm{l}$ ) for river water in areas with similar geology but which are largely un-mined. In comparison average $\mathrm{Fe}$ and $\mathrm{SO}_{4}{ }^{2-}$ concentrations in the Almond River waters are notably higher (Fe 0.64$\left.2.64 \mathrm{mg} / \mathrm{l}, \mathrm{SO}_{4}{ }^{2-}-96.2-244\right)$. This is a likely to be a consequence of mine water discharge at 
the numerous mine sites in the catchment. The elevated concentration of Fe>0.5 $\mathrm{mg}^{-1}$ also indicates that river water ecology throughout the catchment is likely to be adversely impacted by Fe precipitate formation.

\begin{tabular}{lcccccccccccc}
\hline Fe $_{\text {tot }}$ & $\mathbf{1}$ & $\mathbf{2}$ & $\mathbf{3}$ & $\mathbf{4}$ & $\mathbf{5}$ & $\mathbf{6}$ & $\mathbf{7}$ & $\mathbf{8}$ & $\mathbf{9}$ & $\mathbf{1 0}$ & $\mathbf{1 1}$ & $\mathbf{1 2}$ \\
\hline Median mgl $^{-1}$ & 1.27 & 1.20 & 1.59 & 1.30 & 0.88 & 1.18 & 1.30 & 1.02 & 0.92 & 0.79 & 0.78 & 0.68 \\
Mean mgl $^{-1}$ & 2.37 & 1.60 & 1.67 & 1.49 & 1.07 & 1.21 & 1.26 & 1.13 & 1.07 & 0.95 & 0.93 & 0.81 \\
Max mgl $^{-1}$ & 19.70 & 17.00 & 6.36 & 8.12 & 4.71 & 5.13 & 4.97 & 4.41 & 4.18 & 5.95 & 6.18 & 4.17 \\
Low flow gs $^{-1}$ & 0.01 & 0.04 & 0.09 & 0.07 & 0.07 & 0.10 & 0.31 & 0.39 & 0.39 & 0.26 & 0.28 & 0.37 \\
High flow gs $^{-1}$ & 3.06 & 4.68 & 9.45 & 9.71 & 10.10 & 15.38 & 30.16 & 50.27 & 46.62 & 49.06 & 50.40 & 34.74 \\
\hline so $_{4}^{2-}$ & \multicolumn{1}{c|}{} & & & & & & & & & \\
\hline Median mgl $^{-1}$ & 91.90 & 127.50 & 131.50 & 178.55 & 176.00 & 177.00 & n.d. & n.d. & n.d. & 124.00 & n.d. & 114.00 \\
Mean mgl $^{-1}$ & 96.22 & 132.13 & 132.45 & 244.19 & 230.74 & 192.44 & n.d. & n.d. & n.d. & 120.60 & n.d. & 113.89 \\
Max mgl $^{-1}$ & 196.00 & 240.00 & 217.00 & 686.00 & 572.00 & 525.00 & n.d. & n.d. & n.d. & 202.00 & n.d. & 186.00 \\
Low flow gs $^{-1}$ & 2.38 & 9.25 & 20.59 & 49.42 & 53.89 & 62.88 & n.d. & n.d. & n.d. & 161.19 & n.d. & 230.28 \\
\hline
\end{tabular}

\begin{tabular}{lccccccc}
\hline Fe $_{\text {tot }}$ & $\mathbf{1 3}$ & $\mathbf{1 4}$ & $\mathbf{1 5}$ & $\mathbf{1 6}$ & $\mathbf{1 7}$ & $\mathbf{1 8}$ & $\mathbf{1 9}$ \\
\hline Median mgl $^{-1}$ & 0.68 & 0.68 & 0.96 & 2.48 & 0.40 & 1.22 & 0.80 \\
Mean mgl $^{-1}$ & 1.09 & 1.55 & 2.64 & 2.08 & 0.64 & 1.34 & 1.05 \\
Max mgl $^{-1}$ & 6.15 & 33.00 & 5.83 & 19.00 & 3.93 & 7.82 & 6.44 \\
Low flow gs $^{-1}$ & 0.01 & 0.04 & 0.31 & 0.21 & 0.01 & 0.06 & 0.04 \\
High flow gs $^{-1}$ & 0.67 & 4.00 & 5.27 & 15.74 & 1.17 & 6.90 & 4.17 \\
\hline
\end{tabular}

Table 2- Concentration and Load of $\mathrm{Fe}_{\text {tot }}$ and $\mathrm{SO}_{4}{ }^{2-}$ in Almond Surface Waters 


\subsection{Flow Dependency}

Concentration of $\mathrm{Fe}_{\text {tot }}$ and $\mathrm{SO}_{4}{ }^{2-}$ in Almond surface waters (monitoring points 1-19) when plotted against river flow at the time of sampling show significant flow dependence (

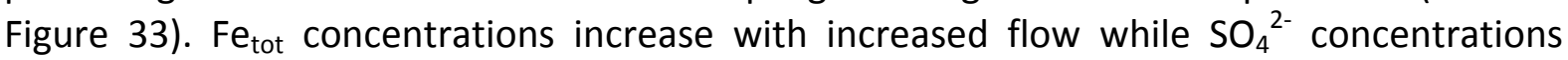
decrease with increased flow. River water $\mathrm{pH}$ was also found to be flow dependent with lower $\mathrm{pH}$ values recorded at increased flow. All the monitoring points in the catchment were found to display these flow relationships.

At monitoring point 12 the relationship of $\mathrm{Fe}_{\text {tot }}$ to flow is approximated to a power law with and an $\mathrm{R}^{2}=0.635$. Flow dependence of Fe in surface waters has been observed, although over shorter monitoring periods with smaller distribution of flow values, in similar heavily mined catchments where it has been related to the re-suspension of diffuse sources of mine and non-mine related river bed Fe sediments (Mayes et al., 2008). The flow dependence of Fe and the widespread mining in the Almond is also considered to be indicative of diffuse stream bed Fe precipitate re-suspension. Precipitate formation when mine waters are discharged to the surface water environment produces solid iron suspended in the water column; some of this is transported downstream while a large majority is deposited in surface waters close to the mine site. Indeed river beds covered in orange Fe are a common feature of the heavily mined areas in the catchment. However because of the high density and long history of mining in the catchment, these river bed precipitates are considered to be almost ubiquitous throughout the main catchment rivers resulting in the flow dependency of iron at all monitoring points.

Sulphate concentration shows an opposing flow dependent relationship- sulphate concentrations are reduced with increased flow. Sulphate does not readily precipitate on exposure to oxygen and therefore does not commonly produce river bed precipitates. The flow dependence of sulphate is likely to be caused by dilution; the mass of sulphate in the river channel remains as a near constant while the river channel water volume and flow increase. The river water $\mathrm{pH}$ shows the same relationship to flow as sulphate. This is considered to be related to the difference in river water source at high and low flow. Groundwaters are generally the dominant water source of river waters at low flow while at high flow rainfall and soil water sources dominate which have lower $\mathrm{pH}$ values than groundwaters. Scatter is observed in the flow dependent relationships potentially due to 
natural variability in (1) discharge rates from mine sites, (2) groundwater contribution, and

(3) the frequency of higher flow events affecting Fe storage and re-suspension.
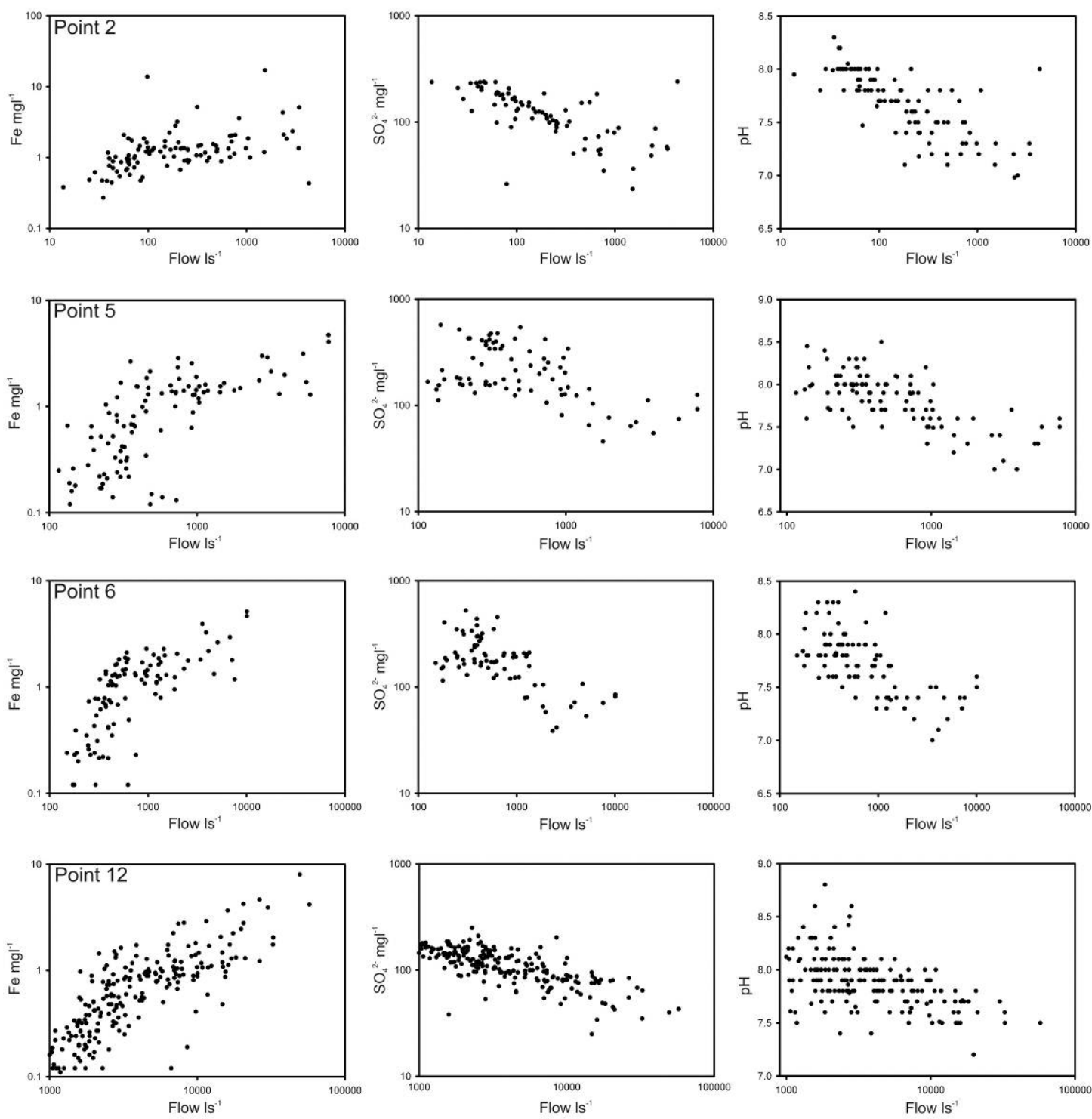

Figure 3- Flow Dependence of $\mathrm{Fe}_{\text {tot }}, \mathrm{SO}_{4}{ }^{2-}$ and $\mathrm{pH}$ in Almond Surface Waters

\subsection{Fe Speciation}

As stated above Fe in mine waters discharged to oxygen rich river waters has a tendency to form $\mathrm{Fe}(\mathrm{OH})_{3}$ precipitates. Figure 44 shows the Almond surface waters plotted on an Eh-pH diagram with Fe species stability fields. No Eh data were available for the samples so dissolved oxygen measurements, ranging from $6-13 \mathrm{mg} / \mathrm{l}$, were used to estimate a mean Eh 
value of $0.5 \mathrm{~V}$ to plot the results. This generally plots waters in the $\mathrm{Fe}(\mathrm{OH})_{3}$ region, although some of the higher Fe values are approaching the transition towards the $\mathrm{Fe}^{2+}$ region. This is significant because the transition is generally graded between the Fe stability regions (Freeze and Cherry 1979).

Since 2007 SEPA have monitored river waters at a number of monitoring points for both $\mathrm{Fe}_{\text {tot }}$ and $\mathrm{Fe}<0.45 \mu \mathrm{m}$. Figure 55 shows the averaged low flow and high flow split between $\mathrm{Fe}>0.45 \mu \mathrm{m}$ and $\mathrm{Fe}<0.45 \mu \mathrm{m}$ and the corresponding $\mathrm{pH}$. It should be noted that there is some indication that a $<0.45 \mu \mathrm{m}$ filter, which is generally accepted to filter out all the solid chemical species in water sample, may allow small amounts of solid Fe complexes into the sample (Apello and Postma 2005). With this limitation in mind the diagram indicates that while $\mathrm{Fe}_{\text {tot }}$ increases at higher flow values related to the re-suspension of $\mathrm{Fe}(\mathrm{OH})_{3}$ described above, $\mathrm{Fe}<0.45 \mu \mathrm{m}$ also increase indicating a greater proportion of the dissolved iron species, $\mathrm{Fe}^{2+}$. The reason for this $\mathrm{Fe}<0.45 \mu \mathrm{m}$ increase is related to the reduction in $\mathrm{pH}$ at high flow, shown by the $\mathrm{pH}$ values on the diagram and the relationship in Figure 33 . The Eh$\mathrm{pH}$ diagram of Almond waters suggests the lower $\mathrm{pH}$ causes the partial dissolution of the resuspended $\mathrm{Fe}(\mathrm{OH})_{3}$ as $\mathrm{Fe}^{2+}$. The hydrological conditions in the river catchment, therefore not only cause the re-suspension of diffuse iron, $\mathrm{Fe}(\mathrm{OH})_{3}$, but result in water chemistry changes which affect the behaviour of iron in surface water. 


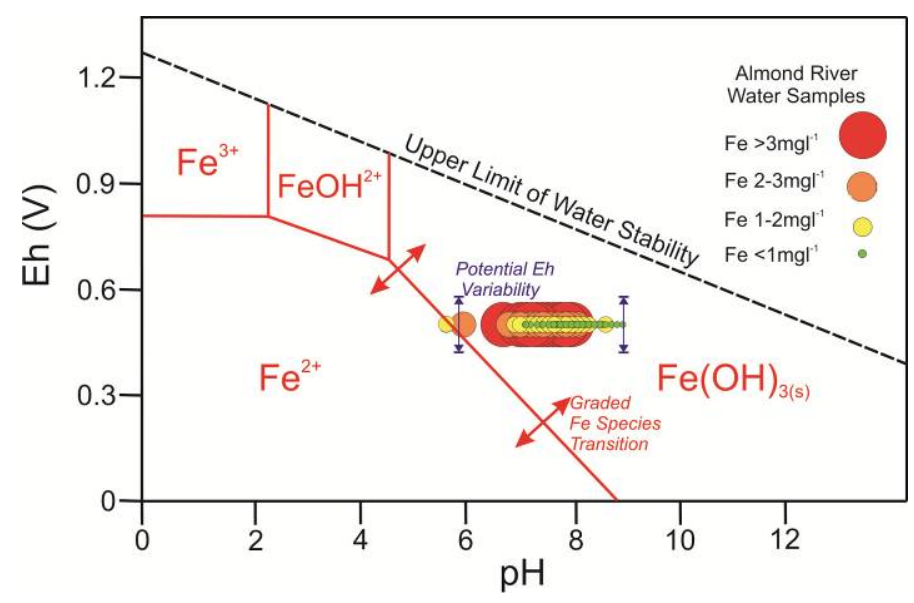

Figure 4 - Eh-pH diagram and Fe species stability in Almond Surface Waters

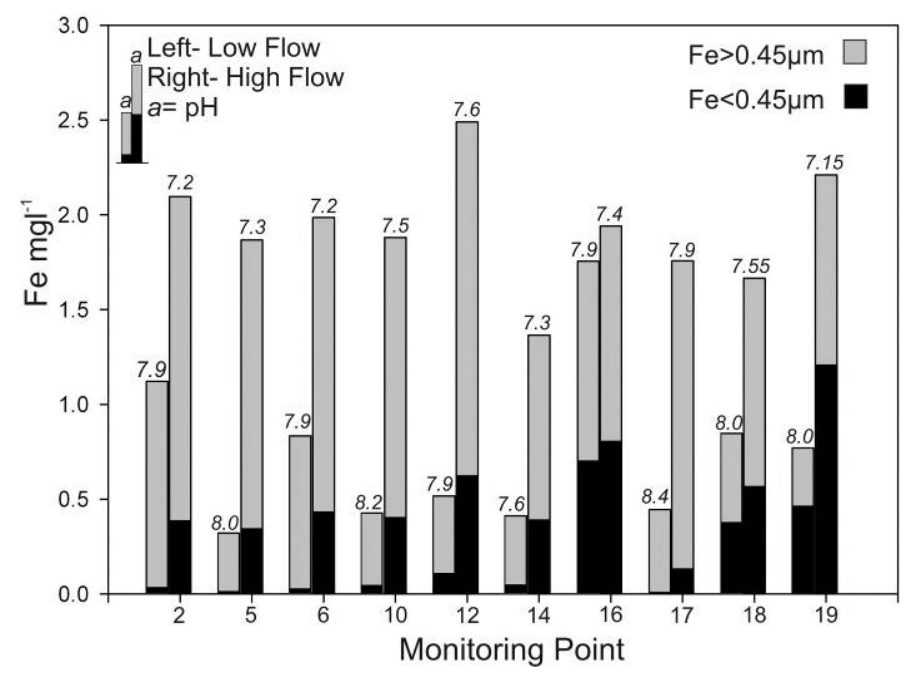

Figure 5 - Distribution of Dissolved Fe, Solid Fe and pH in Almond Surface Waters

The flow-concentration and $\mathrm{pH}$ relationship described above indicates that $\mathrm{Fe}$ and $\mathrm{SO}_{4}{ }^{2-}$ concentrations in surface water will best represent direct impact of mining on water quality at low flow values. At higher flow values the input of iron from direct mine related inputs is likely masked by the re-suspension of diffuse sources of river bed Fe precipitates (Mayes et al., 2008). Iron concentrations at high flow maybe useful as an indication of the amount and location of the 'stored' river bed iron. 


\subsection{Iron and Sulphate Loading}

Concentration data and averaged daily flow values have been used to calculate the surface water load of $\mathrm{Fe}$ and $\mathrm{SO}_{4}{ }^{2-}$ in river waters across the Almond River Catchment (Table 1- Fe load-points 1-19, $\mathrm{SO}_{4}{ }^{2-}$ load- points $1-7,10$ and 12 ). Load is defined here as a measure of the total mass of iron or sulphate passing each monitoring point. Figure 66 shows a box plot distribution of loading values for iron and sulphate at monitoring points 1-12 along in the Almond River during low flow events 1994-2008. The box plots for the load distribution at each monitoring point show the mean and $5^{\text {th }}, 10^{\text {th }}, 25^{\text {th }}, 50^{\text {th }}$ (median) $75^{\text {th }}, 90^{\text {th }}, 95^{\text {th }}$, percentiles. Geometric mean is used for the iron loading values due to the power law relationship of iron and flow outlined previously. The mean load value of the distribution at each point is joined by the dashed line to give a visual representation of the mean loading profile along the Almond River. An upward trend on the loading profile represents the input of fresh iron or sulphate, whilst a downward trend represents, in the case of iron, deposition of $\mathrm{Fe}(\mathrm{OH})_{3}$ from the water column to the river bed, or for sulphate, dilution.

The plots show between a 1 and 2 order magnitude increase in loading of both iron and sulphate from one end of the catchment (point 1) to the other (point 12). This is a clear indication of the discharge of iron and sulphate heavy mine waters, controlled by pyrite oxidation at the mine site, and the resulting impact on the quality of surface water.
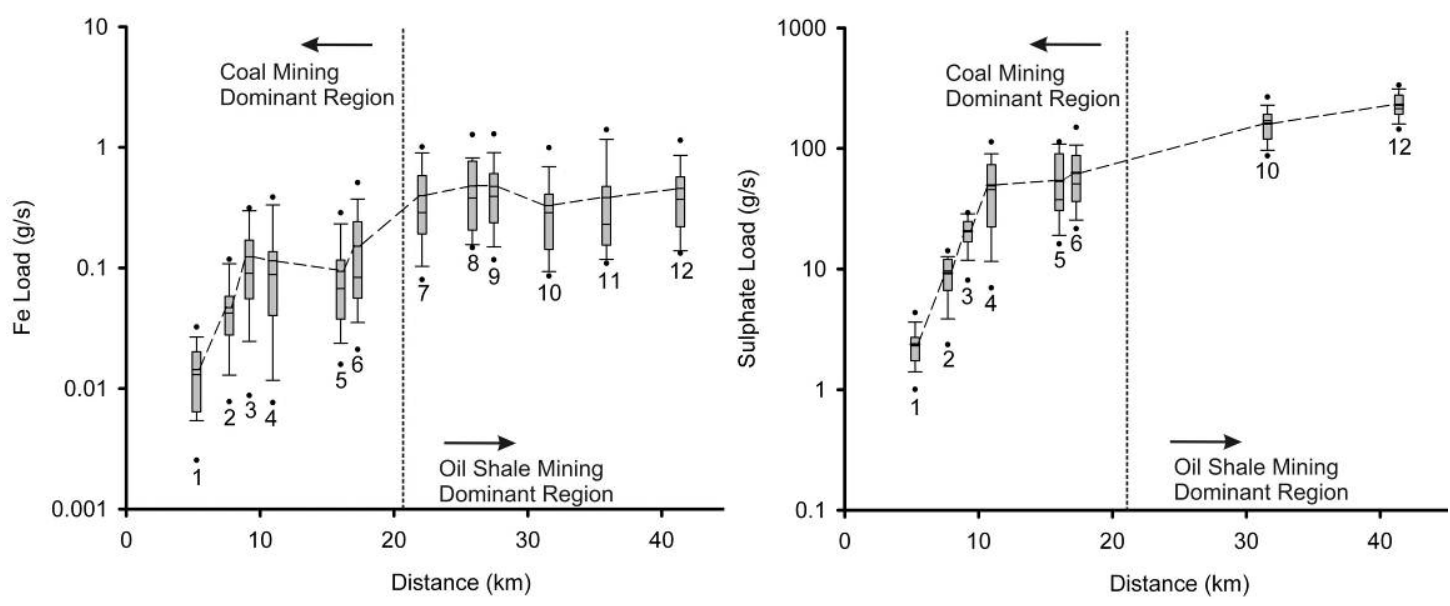

Figure 6- Box Plot of the Distribution of $\mathrm{Fe}_{\text {tot }}$ and $\mathrm{SO}_{4}{ }^{2-}$ at Low Flow 
The geographic divide and distribution of coal and oil shale mining (Figure 2) in the catchment allows the detailed interpretation of load increases calculated from water quality monitoring data. Figure 777 displays the low (A) and high flow (B) iron load distribution calculated at all 19 monitoring points across the Almond River Catchment. Sulphate loading is not included in Figure 777as sulphate data was limited. A summary of the load difference and the relationship to specific regions of concern or 'hotspots' is presented in Table 33.

\begin{tabular}{|c|c|c|c|c|}
\hline $\begin{array}{l}\text { Monitoring } \\
\text { Points }\end{array}$ & $\begin{array}{c}\text { Fe load } \\
\text { difference } \\
(\mathrm{g} / \mathrm{s}) \\
\end{array}$ & $\begin{array}{l}\text { Coal/Oil } \\
\text { Shale }\end{array}$ & Source Area & Comments \\
\hline $1 \rightarrow 2$ & 0.03 & Coal & Harthill (North) & Direct input from mine sites along the How Burn tributary \\
\hline $2 \rightarrow 3$ & 0.05 & Coal & Harthill and Whitburn & $\begin{array}{l}\text { Influx of mine impacted waters from the unmonitored upper reaches of the } \\
\text { Almond River prior to confluence with Howburn. Numerous coal mine } \\
\text { waste and subsurface mines discharge waters in the surrounding area }\end{array}$ \\
\hline $3 \rightarrow 4$ & -0.02 & - & - & River bed deposition of Fe precipitates \\
\hline $4 \rightarrow 5$ & $\mathbf{0}$ & Coal & Bathgate & $\begin{array}{l}\text { Likely input from mine sites in the area possibly balanced by river bed } \\
\text { deposition of Fe precipitates }\end{array}$ \\
\hline $5 \rightarrow 6$ & 0.03 & Coal & $\begin{array}{l}\text { Bathgate, Harthill and } \\
\text { Whutburn }\end{array}$ & Large mines including Polkemmet and Whitrigg colliery \\
\hline $6 \rightarrow 7$ & 0.21 & $\begin{array}{l}\text { Coal and Oil } \\
\text { Shale }\end{array}$ & $\begin{array}{l}\text { West Calder, Addiewell, } \\
\text { Muldron Forest and } \\
\text { Harthill }\end{array}$ & $\begin{array}{l}\text { Breich Water tributary is impacted by numerous coal mine and mine } \\
\text { waste sites including Woodmuir Colliery and Levenseat as well as oil } \\
\text { shale mine and mine waste sites including the Westwood, Hermand and } \\
\text { Five Sisters }\end{array}$ \\
\hline $7 \rightarrow 8$ & 0.08 & Oil Shale & Oakbank & Oakbank oil shale mines and large volumes of oil shale waste \\
\hline $8 \rightarrow 9$ & $\mathbf{0}$ & Oil Shale & Oakbank & $\begin{array}{l}\text { Likely input from mine sites in the area possibly balanced by river bed } \\
\text { deposition of Fe precipitates }\end{array}$ \\
\hline $9 \rightarrow 10$ & -0.13 & - & - & River bed deposition of Fe precipitates \\
\hline $10 \rightarrow 11$ & 0.02 & Oil Shale & Broxburn & $\begin{array}{l}\text { Numerous oil shale mine sites, reinstated opencasts and } 10 \text { 's of millions } \\
\text { of tons of oil shale waste }\end{array}$ \\
\hline $11 \rightarrow 12$ & 0.09 & Oil Shale & Ingliston & $\begin{array}{l}\text { Possible direct discharge from oil shale workings directly below the } \\
\text { Almond River }\end{array}$ \\
\hline
\end{tabular}

Table 3- Fe loads and mine source areas in the Almond Catchment (Source areas are shown in Figure 7)

Coal and oil shale mines and mine wastes are all likely to contribute to point and diffuse mine contaminant sources within their respective areas. The close correlation between the load increase in both iron and sulphate, as the products of pyrite oxidation at the mine site, in Figure 66, even with the omission of points $7,8,9$ and 11 would seem to support this interpretation. However, only the black unprocessed shales found at the oil shale waste sites, and not the processed shales, will contribute $\mathrm{Fe}$ and $\mathrm{SO}_{4}$ through the oxidation of pyrite. Other potential sources of iron which may be of influence on the observed results include urban drainage, potentially derived from anticaking agents used in road salts (Paschka et al, 1999) and sewage treatment works, as well as natural sources such as peat bogs (Fenner et al, 2001). 


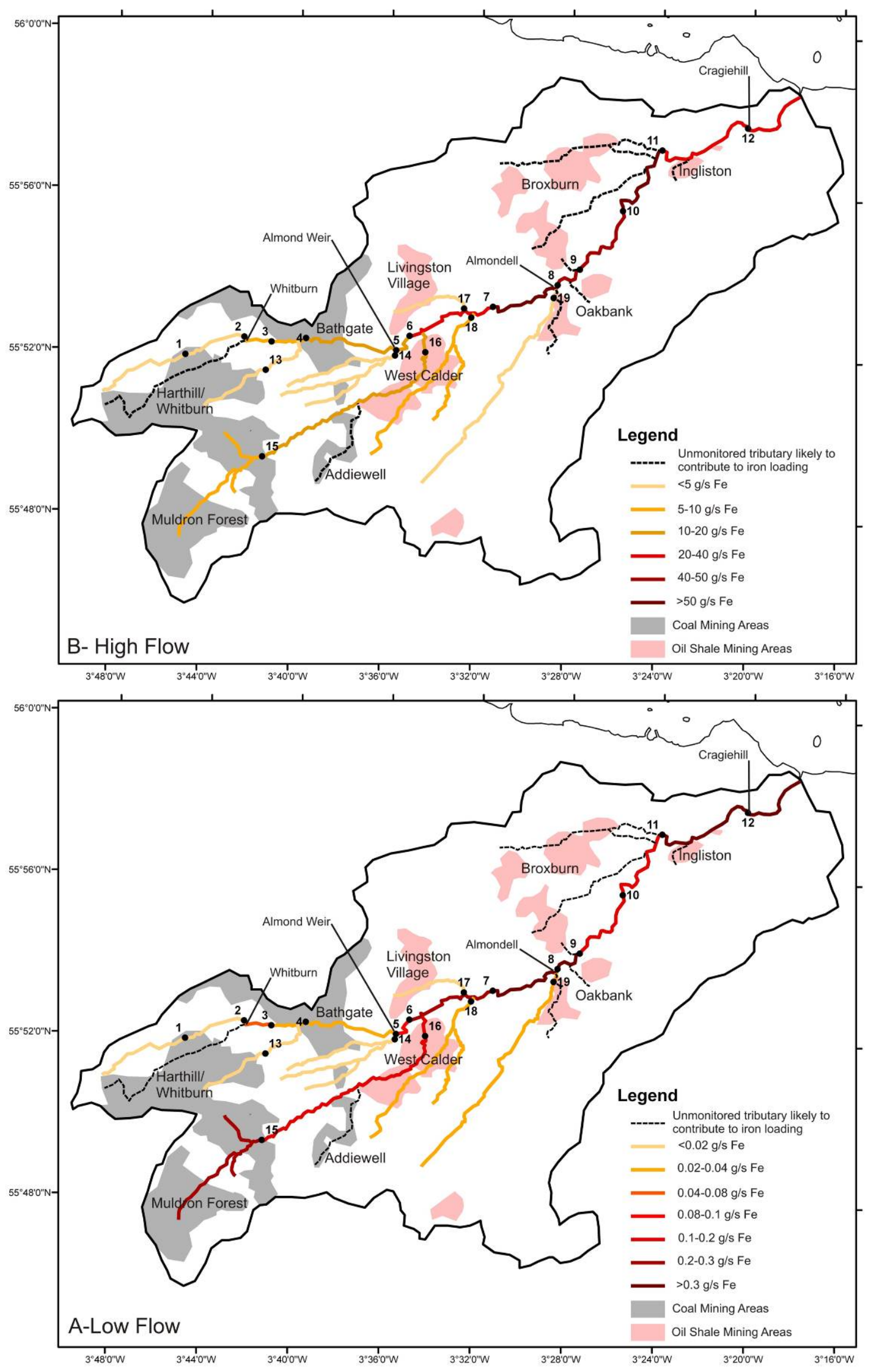

Figure 7 - Principal Mining Areas and Iron Loading under (A) Low Flow and (B) High Flow in Monitored Tributaries 


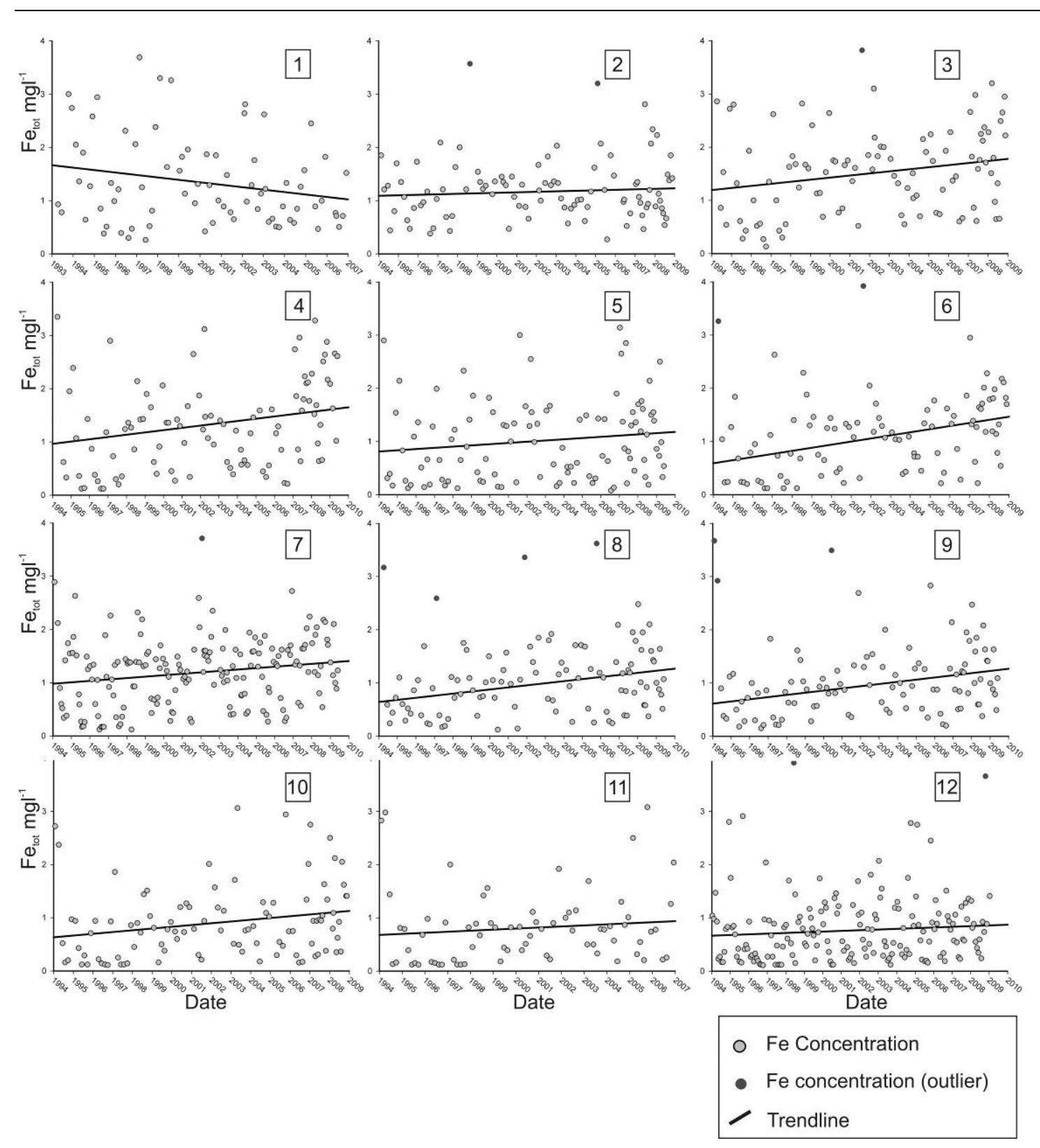

Figure 8 - Fe monitoring data 1994-2008 at 12 sample stations on the principal Almond tributary

\subsection{Fe Trends}

$\mathrm{Fe}_{\text {tot }}$ concentrations in river waters at the 12 monitoring points on the main Almond tributary were considered in relation to time over the 1994-2008 sampling period in order to identify any potential temporal trends. Figure 888 displays the trend of $\mathrm{Fe}_{\text {tot }}$ for each of the 1-12 main Almond River tributary monitoring points. Significant scatter is observed in the data related to the flow dependence of the $\mathrm{Fe}(\mathrm{OH})_{3}$ iron species in the surface waters, 
however, in generally all the monitoring points, except Point 1 , show a shallow upward trend in Fe concentration in the river waters from 1994-2008. A possible explanation for this is that although mining came to a close from 1960-1985 (depending on mined resource), it can take several decades before the main water quality impacts associated with mining occur because of extended groundwater recovery times in heavily mine areas. Indeed the main interconnected 'pond' in the Whitburn area was still in a phase of groundwater recovery in the late 1990s (Chen et al., 1999). The uncontrolled discharge of mine waters to the surface water environment even from mines not directly connected to the Whitburn 'pond' may therefore have been delayed due to reduced groundwater levels in the region. When discharge does occur mine waters are initially in the 'vestigial acidity' phase when contaminant release and Fe concentrations are greatest, as described by Younger (1997). This vestigial acidity phase continues for several decades, hence why an upward trend is observed in recipient surface waters. As mine waters move into the 'juvenile acidity' phase Fe concentrations move to a lower asymptotic concentration (Younger 2000a) and a general reduction in Fe in recipient surface waters might be expected.

\subsection{Attenuation and Cumulative Loading}

Some river sections of the Almond are dominated by the deposition of the $\mathrm{Fe}(\mathrm{OH})_{3}$ iron species on the river bed, while other show increases in Fe load related to mine discharge The cumulative low flow iron load increase and reduction, termed attenuation (Kimball et al., 2002), can be used to give a useful quantitative measure of the relative impact of coal and oil shale mining in the catchment. Kimball et al (2002) and Mayes et al (2008) define cumulative in-stream loading as the sum of all loadings in the reaches where a positive change in loading was measured. Cumulative in-stream attenuation is taken as the sum of the loadings in all reaches that recorded a negative change in loading. The Almond River flowing between point 1 and 12 is considered in these calculations, smaller tributaries monitored with points 13-19 are omitted; except in the determination of the amount of increase directly attributable to oil shale mining between point 6 and 7 . This is calculated on the assumption that the 'West Calder' oil shale area contributes approximately the same amount of low flow load at point 16 as point 18. Therefore the load difference between point 6 and 7 attributed to oil shale mining is calculated at $0.117 \mathrm{~g} / \mathrm{s}(0.055 \mathrm{~g} / \mathrm{s}$ on the point 16 and point 18 tributaries and $0.007 \mathrm{~g} / \mathrm{s}$ on the point 17 tributary). The contribution of coal 
between point 6 and 7 is therefore calculated as $0.086 \mathrm{~g} / \mathrm{s}$ as being the difference between the oil shale load contribution and the total load increase between 6 and 7 .

Omitting points $13-19$ prevents a potentially unfair biased towards coal mining caused by the lack of iron monitoring on tributaries closest to oil shale mining areas, particularly in the north of the catchment, as well as problems associated with flow estimation on these tributaries. It should be noted that both the loading and attenuation values are likely to be underestimations of the true values because, as deposition is also possibly occurring on river sections even where a load reduction is not observed.

\begin{tabular}{lccc}
\hline & Coal & & Oil Shale \\
\hline Cumulative Instream Loading (g/s) & 0.21 & & 0.31 \\
Cumulative Instream Attenuation (g/s) & & 0.154 & \\
\hline
\end{tabular}

Table 4- Cumulative Low Flow in-stream Loading and Attenuation on the Main Almond Tributary

Table 443 indicates, whilst being mindful of the limitations discussed, that coal and oil shale mining regions both significantly contribute to Fe loading on the main Almond tributary and that oil shale, at $0.31 \mathrm{~g} / \mathrm{s}$, contributes more than the coal region, at $0.21 \mathrm{~g} / \mathrm{s}$. The cumulative in-stream attenuation of $0.154 \mathrm{~g} / \mathrm{s}$ suggests that approximately $30 \%$ of the total load discharged to the Almond River is attenuated by deposition on to the river bed. This value agrees with the load reduction value observed between 15 and 16 (of 33\%), which was not included in these calculations. As mentioned earlier, this value is likely to be much higher for the whole catchment as deposition is thought to be occurring on river beds even when a load reduction is not observed. This is supported by the observation that high flow load increases occur on the majority of monitored tributaries in the catchment (Figure 7B): as in order for a significant high flow load increase to occur iron precipitates must have been previously deposited on the river bed. Also, consideration of the difference in low flow and high flow load values indicates that load is increased in some cases by over 2 orders of magnitude (eg. Point 110.28 to $50.4 \mathrm{~g} / \mathrm{s}$ ) indicating the significance of re-suspension of diffuse stream bed sources of iron at high flow.

If we consider all the currently monitored tributaries in the catchment it would appear coal not oil shale contributes more iron loading to the catchment rivers, however, this is an 
unfair comparison because of the lack of monitoring in the one of the main oil shale mined areas- 'Broxburn'. Nevertheless, the cumulative loading comparison is a useful one as it shows in a quantitative manor that iron loading and water quality is significantly impacted by mine discharge inputs from both coal and oil shale mining.

\subsection{Major Ion Water Chemistry}

The major ion chemistry for the Almond River water is displayed in Figure 999; it indicates significant variation in water chemistry along the course of the river related to source. At point 1 the river water displays a calcium bi-carbonate dominant signature representing a significant component of groundwater entering the river. The Coal Measures Group, which underlies this section of the river, displays elevated and moderately elevated concentrations of bi-carbonate (median $\mathrm{HCO}_{3} 456 \mathrm{mg} / \mathrm{L} ; 10^{\text {th }}-90^{\text {th }}$ percentile range $251-510 \mathrm{mg} / \mathrm{L}$ ) calcium $\left(10^{\text {th }}\right.$ to $90^{\text {th }}$ percentile range $3.4-76.6 \mathrm{mg} / \mathrm{l}$, median $\left.50.2 \mathrm{mg} / \mathrm{l}\right)$ and magnesium $\left(10^{\text {th }}\right.$ to $90^{\text {th }}$ percentile range $1.08-43.3 \mathrm{mg} / \mathrm{l}$, median $19 \mathrm{mg} / \mathrm{l}$ ), with local variations (O Dochartaigh et al, 2011) and is likely to be responsible for the calcium bi-carbonate dominance. Between points $2-5$, in the predominantly coal mined area, calcium, magnesium and sulphate are increasing dominant indicating a significant proportion of river water is likely to be sourced from coal minewater (Younger, 2001; O Dochartaigh et al., 2011).

In the oil shale mined areas, points 6-12, which are significantly more urbanised, sodium and chloride are dominant. Discharge of sodium and chloride (up to $1000 \mathrm{mg} / \mathrm{l}$ ) dominant mine waters has been recorded associated with shale spoil discharge elsewhere in the UK (Banks et al. 1997b). It is possible that the black unprocessed component of the oil shale mine wastes discharge sodium chloride dominant waters flushed out from residual pore waters derived at depth and contained in the shale. This together with a component of sewage effluent discharge from sewage works and urban areas (Pollard et al., 2001) may explain the sodium chloride dominance of river water in the oil shale mined areas. Therefore while it is clear from iron and sulphate data, presented previously, that both coal and oil shale mined areas contribute contaminants to the environment, their influence on major ion chemistry of the Almond River water differs significantly. 

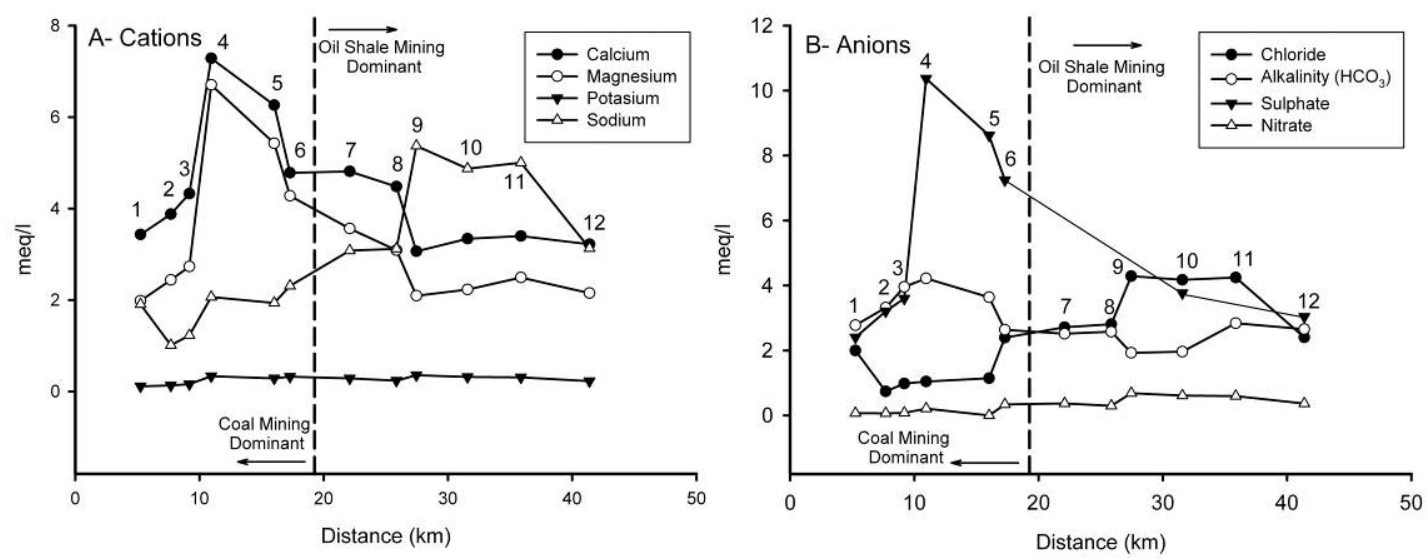

Figure 9 - Major Ion Chemistry of the Almond River Waters- A-cations, B- anions (mean low flow 2005-2006)

\subsection{Conclusions and Recommendations}

This catchment study has highlighted the scale and distribution of coal and oil shale mining in the Almond River catchment. In the study we compared mine site source distribution with surface water contaminant concentrations and loads calculated from 15 years of monthly chemical and flow data at 12 sites in the catchment. The results demonstrate: (1) the continued detrimental impact of both historic coal and oil shale mining on water quality, (2) the diffuse nature of mine water pollution sourced from numerous mine sites within the river catchment, and (3) the flow dependent nature of mine contaminants in surface waters. Of particular significance is the demonstration of a previously poorly characterised relationship between historic unconventional hydrocarbon exploitation from oil shales in Scotland and significant detrimental water quality impact.

Further work on identifying and sampling discharges from both subsurface oil shale mines and mine wastes would help to further quantify the relationship between abandoned oil shale mining and reduced water quality. In addition direct sampling of small coal mine and waste discharges could help to better separate the roles of point and diffuse mine contamination sources. Investigations into the specific nature and chemistry of river bed precipitates would be required to differentiate between diffuse Fe from mine and non-mine sources. This study has also highlighted the importance of regular and widelspread sampling of water quality in catchments subject to diverse mining activities to identifying the various significant sources of contamination. 
The relationships presented here are directly applicable to other similar mined catchments in the UK and across the world. They indicate that a catchment view of mine water contamination should be engaged when assessing numerous, point and diffuse mine water contamination sources. 


\section{References}

Ahmad, M. U. 1974. Coal mining and its effect on water quality. Water Resources Problems Related to Mining. Proceedings No 18, American Water Resources Association.138-148.

Appelo, C.A.J and Postma D., 2005. Geochemistry, Groundwater and Pollution $2^{\text {nd }}$ Edition. A.A. Balkema Publishers.

Banks, D., Younger, P.L., Arnesen, R.T., Iversen, E.R., Banks, S.B., 1997a. Mine-water chemistry: the good, the bad and the ugly, Environmental Geology; 32(3): 157-174.

Banks, D., Burke, S. P., Gray, C. G., 1997b. Hydrogeochemistry of coal mine drainage and other ferruginous waters in north Derbyshire and south Yorkshire, UK. Quarterly Journal of Engineering Geology and Hydrogeology 1997, 30, 257-280.

Bell, F. G. 1996. Dereliction: colliery spoil heaps and their rehabilitation. Environmental and Engineering Geoscience, 2 (1), 85-96.

Blowes D.W., Ptacek C.J., Janbor J.L., Weisener C.G., 2003 The geochemistry of acid mine drainage, In: Treatise on Geochemistry, Vol. 9: Environmental Geochemistry; p. 149-204.

Bowen, G.G., Dussek, C., Hamilton, R.M., 1998. Pollution resulting from abandonment and subsequent flooding of Wheal Jane Mine in Cornwall, UK. In: Groundwater Contaminants and their Migration. Mather, J., Banks, D., Dumpleton, S., Fermor, M._Eds.., Geol. Soc. Spec. Publ. Vol. 128 Geological Society, London, pp. 93-99.

Brock, W.J., 1892. Public health report for Linlithgowshire 1891.

Burns J., 1978. The Use of Waste and Low-Grade Materials in Road Construction: 6. Spent Oil Shale. TRRL Laboratory Report LR818. Transport Research Laboratory, Crowthome.

Cairney, T., Frost, R.C., 1975. A case study of mine water quality deterioration, Mainsforth Colliery, County Durham. J. Hydrol. 25, 275-293.

Cameron I.B., Stephenson D., 1985. British regional geology: The Midland Valley of Scotland. 3rd edition. British Geological Survey, Her Majesty's Stationery office.

Carruthers R.G., Caldwell W., Bailey E.M., Conacher H.R.J., 1927. Oil Shales of the Lothians, Memoirs of the Geological Survey, Scotland, 3rd edition.

Campbell D., Devlin M., D’Arcy B., Sargent R., 1996. Challenges for water quality improvement in the Almond catchment: a consultation document in support of the SWT River Almond integrated catchment management plan. Edinburgh: Forth River Purification Board, unpublished report.

Chen M., Soulsby C., Younger P.L., 1999. Modelling the evolution of minewater pollution at Polkemmet Colliery, Almond Catchment, Scotland, Quarterly Journal of Engineering Geology; 32, 351-362.

Cravotta III, C.A., Bilger, M.D., 2001. Water-quality trends for a stream draining the Southern Anthracite Field, Pennsylvania. Geochemistry: Exploration, Environment, Analysis 1, 33-50.

DECC (Department of Energy \& Climate Change) 2011. The unconventional hydrocarbon resources of Britain's onshore basins- Shale Gas. A British Geological Survey report for the DECC.

Duckham, F. A., 1970. History of the Scottish Coal Industry, Vol. 1 1700-1815.

Edwards, P.J., Maidens, J.B., 1995. Investigations into the Impacts of Ferruginous Minewater Discharges in the Pelenna Catchment on Salmonid Spawning Gravels. (Environment Agency) Welsh Region Internal Report No. PL/EAW/95/6. National Rivers Authority, Cardiff, UK.

España, J.S., Pamo, E.L., Santofimia, E., Aduvire, O., Reyes, J., Barettino, D., 2005. Acid mine drainage in the Iberian Pyrite Belt (Odiel river watershed, Huelva, SW Spain): geochemistry, mineralogy and environmental implications. Applied Geochemistry 20, 1320-1356.

Erg, K., 2005. Changes in groundwater sulphate content in Estonian oil shale mining area, Oil Shale 22, No.3, 275-289 
Haunch S, MacDonald AM, Brown N, McDermott Cl 2013. Flow dependent water quality impacts of historic coal and oil shale mining in the Almond River catchment, Scotland. Applied Geochemistry 39:156-168. doi: 10.1016/j.apgeochem.2013.06.001

Fenner, N., Freeman C., Hughes S., Reynolds B., 2001. Molecular weight spectra of dissolved organic carbon in a rewetted Welsh peatland and possible implications for water quality. Soil Use and Management 17, 106-112.

Francis, E.H., 1983. Carboniferous, Chapter 9, In: Craig GY, Geology of Scotland, Scottish Academic Press, Edinburgh.

Freeze, R.A., Cherry, J.A., 1979. Groundwater. Prentice-Hall, Inc., Englewood Cliffs, N.J.

Gandy, C.J., Smith, J.W.N., Jarvis, A.P., 2007. Attenuation of mining-derived pollutants in the hyporheic zone: a review. Science of the Total Environment 373, 435-446.

Hassan, J.A., 1976. The development of the Coal Industry in Mid and West Lothian 1815-1873, Ph.D Thesis, Strathclyde University, D018256.

Heal, K.V., Salt, C.A., 1999. Treatment of Acidic Metal-Rich Drainage from Reclaimed Ironstone Mine Spoil, Water Science Technology 12, 141-148.

Heal, K.V., Hourmouziadis, D., Vinten, A., 2006. The Performance and Impact of Maintenance on the Whitrigg Bing Leachate Treatment System, June-July 2006. Report for West Lothian Council.

Hedin, R.S., Nairn, R.W., Kleinmann, R.L.P., 1994. Passive Treatment of Coal Mine Drainage. US Bureau of Mines Information Circular 9389. US Department of the Interior, Bureau of Mines, Pittsburgh, PA.

Howes, N.J., Sabine, M., 1998. Survey of Minewaters in Wales 1997-1998. Environment Agency Wales, Llanelli, $145 \mathrm{pp}$.

Jarvis, A.P., Younger, P.L., 1997. Dominating chemical factors in mine water induced impoverishment of the invertebrate fauna of two streams in the Durham Coalfield, UK. Chemistry and Ecology 13, 249-270.

Jarvis, A.P., Moustafa, M., Orme, P.H.A., Younger, P.L., 2006. Effective remediation of grossly polluting, acidic and metal-rich spoil heap drainage using a novel, low-cost, permeable reactive barrier in Northumberland, UK. Environmental Pollution 143, 261-268.

Kerr, P., 1994. Shale Oil: Scotland, the world's pioneering oil industry.

Kimball, B.A., Runkel, R.L., Walton-Day, K., Bencala, K.E., 2002. Assessment of metal loads in watersheds affected by acid mine drainage using tracer injection and synoptic sampling: Cement Creek, Colorado, USA. Applied Geochemistry 17, 1183-1207.

Kimball, B.A., Bencala, K.E., Besser, J.M., 1999. Synthesis of Watershed Characterization for Making Remediation Decisions. U.S. Geological Survey Water-Resources Investigations Report 99-4018A. USGS. pp. 3e7.

Lottermoser, B. G. 2010. Mine Wastes, $3^{\text {rd }}$ ed., Spronger-Verlag Berlin Heidelberg

Louw, S.J., Addison, J., 1985. Studies of the Scottish Oil Shale Industry, volume1, history and mineralogy, Institute of Occupational Medicine, historical research report, TM/85/02.

Mac Donald, A.M., Browne, M.A.E., Smith, N.A., Colman, T., McMillian, A.A., 2003. A GIS of the extent of historical mining activities in Scotland: explanatory notes. British Geological Survey commissioned report, CR/03/331. 12pp.

Mc Adam, A.D., Smith R.A., Ross D.L., 1992. Geology for land use planning: Livingston, British Geological Survey Technical report; WA 92/37.

Mayes, W.M., Gozzard, E., Potter, H.A.B., Jarvis, A.P., 2008. Quantifying the importance of diffuse minewater pollution in a historically heavily coal mined catchment, Environmental Pollution 151, 165-175.

Neal, C., Rowland, P., Scholefield, P., Vincent, C., Woods, C., Sleep, D., 2011. The Ribble/Wyre observatory: major and trace elements in river draining rural headwaters to the heartlands of the NW England historic industrial base. The Science of the Total environment 409, 1516-1529.

Nordstrom, D. K. 2011. Hydrochemical processes governing the origin, transport and fate of major and trace elements from mine waste and mineralized rock to surface waters. Applied Geochemistry 26, 1777-1791. 
O Dochartaigh, B.E.; Smedley, P.L.; MacDonald, A.M.; Darling, W.G.; Homoncik, S., 2011. Baseline Scotland : groundwater chemistry of the Carboniferous sedimentary aquifers of the Midland Valley. British Geological Survey 2011; 91pp. OR/11/021.

Oglethorpe, M.K., 2006. Scottish colliers: an inventory of the Scottish coal industry in the nationalised era. The royal commission on the ancient and historical monuments of Scotland.

Pollard, P., Devlin, M., Holloway, D., 2001. Managing a complex river catchment: a case study on the River Almond, The Science of the Total Environment 265, 343-357.

Paschka, M.G., Ghosh, R.S., Dzombak, D.A., 1999. Potential water quality effects from iron cyanide anticaking agents in road salt. Water Environment Research 71, 1235e1239.

Rees, S.B., Bowell, R.J., Wiseman, I., 2002. Influence of mine hydrogeology on mine water discharge chemistry, In: Younger PL, Robins NS, Mine water hydrogeology and geochemistry, Geological Society, London, Special Publications 198, 379-390.

SEPA, Forth Area Draft Management Plan 2009-2015.

Sherwood, P.T., 1994. The use of waste materials in fill and capping layers. TRL contractor report CR 353. Transport Research Laboratory, Crowthorne.

Soulsby, C., Malcolm, I.A., Youngson, A.F., Tetzlaff, D., Gibbins, C.N., Hannah, D.M., 2005. Groundwater-surface water interactions in upland Scottish river: hydrological, hydrochemical and ecological implications. Scottish Journal of Geology 41, 39-49.

Wood, S.C., Younger, P.L., Robins, N.S., 1999. Long-term changes in the quality of polluted minewater discharges from abandoned coal workings in Scotland. Q J Eng Geol 32_1.:69-79.

Winter, M.G., 2001. Spent Oil Shale use in Earthwork Construction, Engineering Geology 60, 285-294.

Yen, T.F., Chilingarain, G.V., 1976. Oil Shale. Developments in petroleum science 5. Elsevier scientific publishing company.

Younger P., 1994. Minewater pollution: the revenge of old king coal. Geoscientist; 4(5):6-8.

Younger, P.L., 1995. Hydrogeochemistry of Minewaters Flowing from Abandoned Coal Workings in County Durham. Q J Eng Geol 28, S101-S113.

Younger, PL., 1997. The Longevity of Minewater Pollution: A Basis for Decision-Making. Science of the Total Environment 194/195, 457-466.

Younger, P.L., 1998. Coalfield abandonment: geochemical processes and hydrochemical products. In: Energy and the Environment. Geochemistry of Fossil, Nuclear and Renewable Resources. Nicholson, K. _Ed., Soc. Environ. Geochem. Health McGregor Science, Aberdeenshire, pp. 1-24.

Younger, P.L., 2000a. Predicting temporal changes in iron concentrations in groundwaters flowing from abandoned deep mines: a first approximation. Journal of Contaminant Hydrology 44, 47-69.

Younger, P.L., 2000 b. Iron. In: D’Arcy, B.J., Ellis, J.B., Ferrier, R.C., Jenkins, A., Dils, R. (Eds.), Diffuse Pollution Impacts: The Environmental and Economic Impacts of Diffuse Pollution in the UK. Chartered Institution of Water and Environmental Management, pp. 95e104.

Younger, P.L., 2001. Mine water pollution in Scotland: nature, extent and preventative strategies, The Science of the Total Environment 265, 309-326. 